\title{
Effect of natural and anthropogenic acidification on aluminium distribution in forest soils of two regions in the Czech Republic
}

\author{
Lenka Pavlů $^{1} \cdot$ Luboš Borůvka $^{1} \cdot$ Ondřej Drábek $^{1}$. \\ Antonín Nikodem ${ }^{1}$
}

Received: 19 March 2019 / Accepted: 25 June 2019 / Published online: 2 November 2019

(C) The Author(s) 2019

\begin{abstract}
To elucidate the dynamics of aluminium (Al), an element potentially toxic and strongly affected by acidification processes, in soils, we selected two regions that were similar in relief, soil types, and vegetation cover but differed markedly in their history of acid precipitation: the Jizerské Mountains (anthropogenically acidified) and the Novohradské Mountains (naturally acidified) in the Czech Republic. The levels of $\mathrm{Al}$ forms (exchangeable and organically bound) associated with different environmental impacts were measured and univalent, divalent and trivalent $\mathrm{Al}$ species were quantified using HPLC/IC. Exchangeable and organically bound $\mathrm{Al}$ concentrations were higher in the anthropogenically acidified area. Only the concentrations of the leastdangerous species, the univalent, in organic soil horizons were similar for both mountains. The concentrations of exchangeable $\mathrm{Al}$ forms were correlated with $\mathrm{Ca}$ concentrations and with $\mathrm{pH}$ in the organic horizon. The known relationship of $\mathrm{Al}$ with soil $\mathrm{pH}$ was stronger in the mineral horizons. Relationships of exchangeable $\mathrm{Al}$ forms concentrations
\end{abstract}

Project funding: The work was supported by the European Regional Development Fund, project Centre for the Investigation of Synthesis and Transformation of Nutritional Substances in the Food Chain in Interaction with Potentially Harmful Substances of Anthropogenic Origin: Comprehensive Assessment of Soil Contamination Risks for the Quality of Agricultural Products (No. CZ.02.1.01/0.0/0.0/16_019/0000845).

The online version is available at http://www.springerlink.com

Corresponding editor: Zhu Hong.

Lenka Pavlů

pavlu@af.czu.cz

1 Department of Soil Science and Soil Protection, Faculty of Agrobiology, Food and Natural Resources, Czech University of Life Sciences Prague, Prague, Czechia with sulphur concentrations or even more with the sulphur calcium molar ratio were found only in the Jizerské Mountains, not in the Novohradské. Generally, the obtained results support the hypothesis that mechanisms differed between natural and anthropogenic acidification.

Keywords Soil acidification $\cdot$ Spruce forest $\cdot$ Soil properties · Aluminium forms · Aluminium species

\section{Introduction}

Soil acidification is a natural process, which is accelerated by human activities. The general principles of this process have been elucidated (e.g., Rengel 2003). Anthropogenic acidification of soils is mainly derived from the burning of fossil fuels, resulting in $\mathrm{SO}_{2}$ and $\mathrm{NO}_{x}$ emission, which are transformed into acids and are deposited in soil. Although fossil fuel emissions have dropped from previously very high amounts in Europe (Kopáček and Veselý 2005), acidifiers have accumulated in soils, and industrial regions have been increasing in Asia (Smith et al. 2011). Soil acidification leads to the loss of nutrient elements (e.g., $\mathrm{Ca}$ and $\mathrm{Mg}$ ) and accelerates the mobilization of potentially toxic elements (e.g., $\mathrm{Al}$ or $\mathrm{Mn}$ ). The release of nutrients (particularly base cations) is the first buffering stage of naturally acidic soils $(\mathrm{pH} \geq 5)$ (Bowman et al. 2008). Aluminium is released into the soil through the hydrolysis of Al hydroxides, silicates and $\mathrm{Al}$ complexes with soil organic matter in acidic soils. The transformation of $\mathrm{Al}$ forms in soils (hydrolysis; dissolution or precipitation of Al-containing minerals; and protonation or deprotonation of organic functional groups) is the main mechanism of $\mathrm{pH}$ buffering in strongly acidic soils with a pH below 5 ( $\mathrm{Li}$ and Johnson 2016). 
The dissolved $\mathrm{Al}$ species determine the potential bioavailability and toxicity of $\mathrm{Al}$. Most consider that $\mathrm{Al}$ is phytotoxic to the majority of plants at soil pH s below 5.5 (Schmitt et al. 2016), subsequently causing $\mathrm{Al}$ to become soluble while simultaneously changing its hydroxide form $\mathrm{Al}(\mathrm{OH})_{3}$ to specific toxic species, such as $\mathrm{Al}(\mathrm{OH})_{2}^{+}, \mathrm{Al}(\mathrm{OH})^{2+}$ and $\mathrm{Al}^{3+}$ (Kinraide 1991). The toxicity of aluminium species to plants qualitatively decreases in the following order: $\mathrm{Al}^{3+}$, $\mathrm{Al}(\mathrm{OH})^{2+}, \mathrm{Al}(\mathrm{OH})_{2}^{+}$. Because aluminium bound to organic complexes is supposed to be nontoxic (Boudot et al. 1994), complexation of $\mathrm{Al}$ with natural organic ligands is important for regulating the concentrations of the highly toxic $\mathrm{Al}^{3+}$ ions in acidic soils and natural waters (Collignon et al. 2012).

The potential toxicity of $\mathrm{Al}$ could result from the complex interactions of $\mathrm{Al}$ with apoplasmic (cell wall), plasma membrane, and symplasmic (cytosol) targets of root cells (Singha et al. 2017), which together with low $\mathrm{pH}$, nutrient loss and nutrient imbalances ( $\mathrm{N}$ versus base cations) affect plant growth and nutrient uptake, increase the risk of plant disease and pests, and decrease plant resistance to extreme climate patterns. All of these can reduce biodiversity in forest ecosystems and forest health (Stevens et al. 2010). Although soil acidification mainly affects the forest ecosystems in Central Europe, it has serious economic impact because it limits commercial production of staple food crops (Gupta et al. 2013).

The two regions selected for this work, the Jizerské Mountains and the Novohradské Mountains (Fig. 1) in the Czech Republic, differ markedly in their history with regard to acidic precipitation. The Jizerské Mountains are strongly affected by anthropogenic acidification and is one of the most damaged areas in the Czech Republic. High concentrations of acidifiers (sulphur dioxide and nitrogen oxides) were emitted to the atmosphere in the past, mainly from thermal power stations in the Czech Republic, Germany and Poland. Bulk deposition of these acidifiers (recalculate to sulphur and nitrogen) reached levels higher than $5 \mathrm{~g}$ of sulphur and $3 \mathrm{~g}$ of nitrogen per square meter per year in the Jizerské Mountains before 1990 (CHMI 2019). Typical forest decline, primarily caused by the direct effect of acid rains (on leaves and needles) and secondarily by nutrient

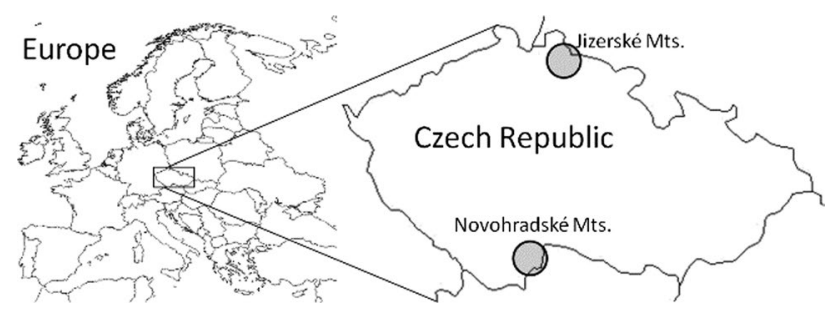

Fig. 1 Location of the studied mountain areas in the Czech Republic loss, is apparent at the tops of these mountains. In contrast, the soils of the Novohradské Mountains, located far from the principal sources of air pollution, are less affected by anthropogenic acidification [bulk deposition of 1-2 g sulphur and $0.1-1 \mathrm{~g}$ nitrogen per square meter per year before 1990 (CHMI 2019)].

The general hypothesis has been that the mechanisms underlying natural and anthropogenic acidification are different. Low soil $\mathrm{pH}$, which is caused by organic acids, does not necessarily represent a high risk for the release of $\mathrm{Al}$ toxic forms to ecosystems due to their complexing ability. In contrast, anthropogenic acidification by mineral acids can lead to the release of potentially toxic forms of Al. Here we aimed to find answers to the following questions: (1) Is $\mathrm{Al}$ speciation affected by the differing acidification level between the two mountain regions? (2) Do the main control mechanisms of the $\mathrm{Al}$ species distribution differ between the two regions?

\section{Materials and methods}

The altitude of both areas falls approximately in the range of 500-1100 m, a.s.l. The average annual temperatures are similar in both areas, in the range of $3-6{ }^{\circ} \mathrm{C}$ depending on the altitude. The annual precipitation amount is higher in the Jizerské Mountains, which can be up to $1500 \mathrm{~mm}$ at the top, than in the Novohradské Mountains, which receives only about $800 \mathrm{~mm}$ per year. Granite (granodiorite) and gneiss form an acidic bedrock in both areas. Haplic or Entic Podzols and Dystric Cambisols (IUSS 2019) are the prevailing soils in both areas. The mor type of humus prevails, whereas the moder humus form is found only at lower altitudes.

The soils in the Jizerské Mountains have been studied in several projects. The area was previously set up with an irregular grid of 98 sampling sites to describe the soil characteristics (Borůvka et al. 2005). These sites differ in tree species composition; spruce [Picea abies (L.) Karst.] or beech (Fagus sylvatica L.) are the dominant trees. The sites also differ in tree age. At each site, there were homogenous production forests with regard to age, from $0-10$ years to more than 100 years old with minimal natural regeneration. Soil samples from 52 selected sites were then used for comparison with soils from the Novohradské Mountains. The pure spruce forest plots were selected to eliminate the differences between soils of spruce and beech forests documented by Tejnecký et al. (2010) and Pavlů et al. (2018). The sampling plots with a forest age exceeding 40 years were preferred to nullify any clear-cut effect. Forest dieback from acid rains at the end of the 1980s and the resulting increase in light gaps led to the expansion of grasses. For several decades, a large area was covered by grasses and difficult to reforest (Pavlů et al. 
2018). The presence of grasses among younger trees considerably changes the soil properties (Borůvka et al. 2005; Drábek et al. 2007). The Novohradské Mountains were also covered by an irregular grid of 51 sampling sites with a spruce forest cover that was older than 40 years (Fig. 2).

One soil pit with dimensions of approximately $50 \times 50 \mathrm{~cm}$ and between 25 and $50 \mathrm{~cm}$ below the topsoil organic horizons was dug as far as possible from trees (minimum $2 \mathrm{~m}$ ) in each site for soil description and sampling. Samples were collected from all sufficiently thick soil horizons. Primarily, one sample was collected from the organic $\mathrm{O}$ (topsoil) horizon and at least one sample from a mineral horizon (cambic or spodic). The samples were air-dried and sieved through a $2-\mathrm{mm}$ mesh. The basic soil characteristics were determined using common methods. The values of $\mathrm{pH}_{\mathrm{H} 2 \mathrm{O}}$ and $\mathrm{pH}_{\mathrm{KCl}}$ were measured potentiometrically using an ion selective electrode. The total $\mathrm{C}, \mathrm{N}$ and $\mathrm{S}$ were measured using an automated analyser LECO CNS-2000 (MI, USA). The pseudo-total Ca and $\mathrm{Mg}$ were extracted with aqua regia (mixture of nitric acid and hydrochloric acid in a molar ratio of 1:3). Molar ratio of $\mathrm{Ca}$ and $\mathrm{S}$ as acidification level indicator (Larssen and Carmichael 2000) was calculated. Different $\mathrm{Al}$ forms were determined according to Drábek et al. (2003). Exchangeable $\mathrm{Al}$ forms were extracted with $0.5 \mathrm{M} \mathrm{KCl}$ solution $\left(\mathrm{Al}_{\mathrm{KCl}}\right)$, and assessment of organically bound $\mathrm{Al}\left(\mathrm{Al}_{\mathrm{ORG}}\right)$ was based on the $\mathrm{Al}$ concentration in $0.3 \mathrm{M} \mathrm{CuCl}_{2}$ extract $\left(\mathrm{Al}_{\mathrm{KCl}}\right.$ concentration as the inorganic form was deducted). The aluminium concentrations in the extracts were determined using a Varian Vista Pro inductively coupled plasma optical emission spectrometer (ICP-OES; Varian, Australia). Al speciation in the $0.5 \mathrm{M} \mathrm{KCl}$ extract was determined using HPLC/IC (Drábek et al. 2005), which separates the $\mathrm{Al}$ forms into three groups according to their charge: $\mathrm{Al}(\mathrm{X})^{1+}\left[\mathrm{Al}(\mathrm{OH})_{2}^{+}, \mathrm{Al}\left(\mathrm{SO}_{4}\right)^{+}, \mathrm{AlF}_{2}{ }^{+}, \mathrm{Al}(\text { oxalate })^{+}\right.$, $\mathrm{Al}(\mathrm{H} \text {-citrate })^{+}$, etc.]; $\mathrm{Al}(\mathrm{Y})^{2+}\left[\mathrm{Al}(\mathrm{OH})^{2+},(\mathrm{AlF})^{2+}\right.$, etc. $]$; and $\mathrm{Al}^{3+}\left[\mathrm{Al}^{3+}\right.$ and transformed hydroxyl $\mathrm{Al}$ polymers $]$.
However, the $\mathrm{Al}(\mathrm{X})^{1+}$ species are co-eluted together with $\mathrm{Al}(\mathrm{Z})^{\leq 0}$ forms, where $\mathrm{Z}$ represents mainly organic ligands.

\section{Calculations and statistics}

STATISTICA 13.3 software (StatSoft, Tulsa, OK, USA) was used for statistical analyses. The data set was first tested for normality (Kolmogorov-Smirnov and Liliefors), which showed that the distribution was clearly non-Gaussian. A double-peak distribution was caused by differences between the organic and mineral soil horizons. Thus, the data set was divided by horizon types, and further analyses were performed separately. Outliers (three-sigma rule of thumb) of each variable were excluded from the data set. Basic statistics such as mean and coefficient of variance (ratio of the standard deviation to the mean; statistical measure of the dispersion of data points in a data series around the mean) were computed. A $t$ test for independent samples by variables was used to identify any differences between the mountain areas. Basic relationships among soil properties were assessed with correlation analyses. A correlation coefficient matrix was expanded with information on significance at different probability levels. Significant relationships were further analysed with a regression analysis.

\section{Results and discussion}

\section{Soil characteristics}

Differences between the soil chemical variables in the studied areas were first assessed with a $t$ test (Table 1). The observed differences in $\mathrm{O}$ horizons are that sulphur and nitrogen concentration are higher in soils of the anthropogenically acidified Jizerské Mountains. This result is in accordance with the findings of Suchara and Sucharová (2002). Surprisingly, pH values were considerably higher
Fig. 2 Sampling sites (filled circle) in the studied areas. Altitude contour lines are shown in the background with altitude of highest mountains (filled triangle)
Jizerské Mountains

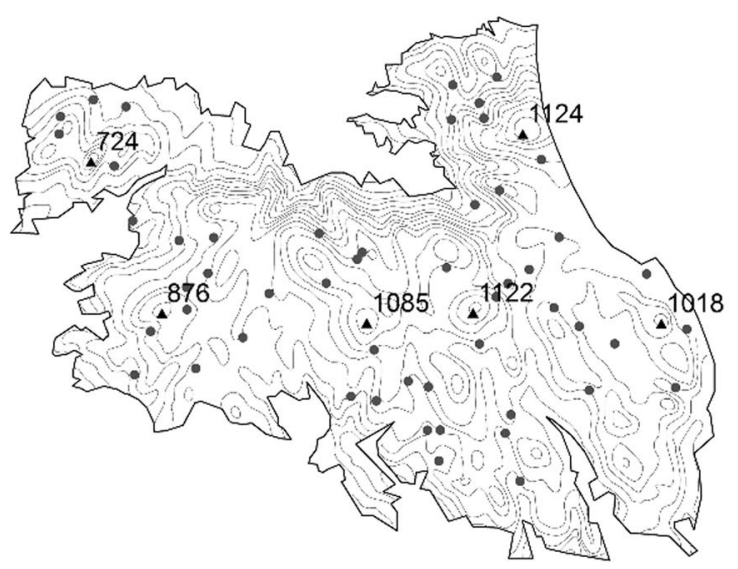

Novohradské Mountains

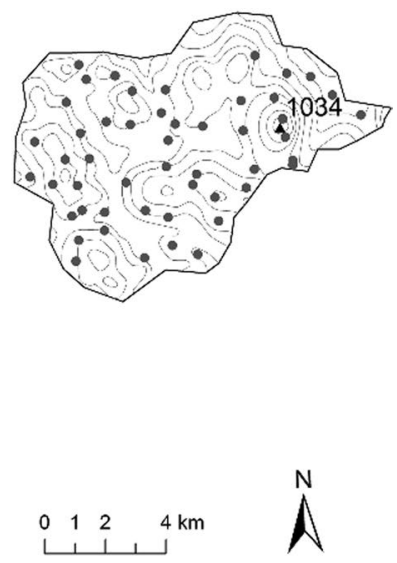


Table 1 Mean values for basic soil characteristics in both areas (JM, Jizerské Mts.; NM, Novohradské Mts.) and in each soil horizon; $N$, sample size; CV, coefficient of variation; bolded $t$ values indicate statistically significant differences between the two areas $(p<0.001)$

\begin{tabular}{|c|c|c|c|c|c|c|c|c|c|c|c|c|}
\hline Horizon & Site & Statistic & $\mathrm{pH}_{\mathrm{H} 2 \mathrm{O}}$ & $\mathrm{pH}_{\mathrm{KCl}}$ & $\mathrm{C}(\%)$ & $\mathrm{S}(\%)$ & $\mathrm{N}(\%)$ & $\mathrm{Mg}\left(\mathrm{mg} \mathrm{kg}^{-1}\right)$ & $\mathrm{Ca}\left(\mathrm{mg} \mathrm{kg}^{-1}\right)$ & $\mathrm{S} / \mathrm{Ca}$ & $\mathrm{Al}_{\mathrm{KCl}}\left(\mathrm{mg} \mathrm{kg}^{-1}\right)$ & $\overline{\mathrm{Al}_{\mathrm{org}}\left(\mathrm{mg} \mathrm{kg}^{-1}\right)}$ \\
\hline \multirow[t]{8}{*}{$\mathrm{O}$} & \multirow[t]{3}{*}{$\mathrm{JM}$} & Mean & 3.88 & 3.13 & 30.19 & 0.35 & 1.57 & 786 & 401 & 14.18 & 1322 & 2957 \\
\hline & & $N$ & 52 & 52 & 52 & 52 & 51 & 50 & 49 & 49 & 52 & 52 \\
\hline & & $\mathrm{CV}$ & 6.69 & 7.68 & 23.29 & 31.17 & 22.10 & 52.35 & 71.80 & 60.28 & 38.54 & 47.84 \\
\hline & \multirow[t]{5}{*}{ NM } & Mean & 3.04 & 2.30 & 31.13 & 0.27 & 1.38 & 790 & 451 & 9.09 & 581 & 1769 \\
\hline & & $N$ & 50 & 49 & 50 & 50 & 50 & 50 & 50 & 47 & 50 & 50 \\
\hline & & $\mathrm{CV}$ & 11.10 & 10.80 & 23.32 & 18.84 & 17.93 & 56.17 & 70.09 & 61.50 & 38.30 & 35.86 \\
\hline & & $t$ & 14.01 & 17.09 & -0.66 & 5.12 & 3.06 & -0.04 & -0.82 & 3.43 & 9.45 & 5.43 \\
\hline & & $p$ & $<0.001$ & $<0.001$ & 0.508 & $<0.001$ & 0.003 & 0.965 & 0.414 & $<0.001$ & $<0.001$ & $<0.001$ \\
\hline \multirow[t]{8}{*}{ B } & \multirow[t]{3}{*}{$\mathrm{JM}$} & Mean & 3.99 & 3.63 & 3.86 & 0.03 & 0.18 & 2763 & 210 & 1.76 & 786 & 1038 \\
\hline & & $N$ & 37 & 37 & 37 & 36 & 37 & 37 & 37 & 35 & 37 & 34 \\
\hline & & $\mathrm{CV}$ & 4.23 & 5.69 & 34.77 & 43.56 & 32.98 & 34.44 & 34.75 & 54.04 & 32.20 & 64.63 \\
\hline & \multirow[t]{5}{*}{ NM } & Mean & 3.25 & 3.56 & 3.15 & 0.06 & 0.17 & 4038 & 172 & 5.14 & 314 & 949 \\
\hline & & $N$ & 54 & 53 & 53 & 52 & 53 & 53 & 52 & 48 & 54 & 52 \\
\hline & & $\mathrm{CV}$ & 8.89 & 5.24 & 55.61 & 39.27 & 47.17 & 45.87 & 63.65 & 60.66 & 35.94 & 48.39 \\
\hline & & $t$ & 14.12 & 1.7 & 2.08 & -6.99 & 0.52 & -3.84 & 1.83 & -6.2 & 12.09 & 0.73 \\
\hline & & $p$ & $<0.001$ & 0.092 & 0.041 & $<0.001$ & 0.601 & $<0.001$ & 0.07 & $<0.001$ & $<0.001$ & 0.467 \\
\hline
\end{tabular}

in the Jizerské Mountains. Similar differences in soil pH in these areas were also reported by Borůvka et al. (2009), but only in a smaller sample set. Low pH values in naturally acidified mountains caused by soil organic acids were also reported by Pohlman and McColl (1988). Organic carbon and potentially mobilized $\mathrm{Ca}$ and $\mathrm{Mg}$ concentrations were similar in both mountains. A different situation was found in the mineral horizons. Only pedogenetically similar horizons were compared (Pavlů et al. 2018). Hydromorphic or humus-enriched spodic B horizons were excluded from statistical analysis. Only $\mathrm{pH}_{\mathrm{H} 2 \mathrm{O}}$ values were higher in the Jizerské Mountains, while the $\mathrm{pH}_{\mathrm{KCl}}$ values were similar in both areas. The sulphur concentration in the mineral horizons is higher in the Novohradské
Mountains. Higher concentrations of $\mathrm{Mg}$ in these horizons were also found in the soils of Novohradské Mountains.

Sucharová et al. (2011) found that the total Al concentration in the organic horizons is approximately three times higher in the Jizerské Mountains than in the Novohradské Mountains. We elucidated the $\mathrm{Al}$ speciation forms to understand the distribution of potentially toxic $\mathrm{Al}$ forms. $\mathrm{Al}_{\mathrm{ORG}}$ represents nontoxic aluminium bound to organic complexes (Boudot et al. 1994), and $\mathrm{Al}_{\mathrm{KCl}}$ represents an available $\mathrm{Al}$ forms that can be released from the soil sorption complex. The concentrations of both $\left(\mathrm{Al}_{\mathrm{ORG}}, \mathrm{Al}_{\mathrm{KCl}}\right)$ were significantly higher in the $\mathrm{O}$ horizons of the Jizerské Mountains. In the mineral horizons, the concentration of $\mathrm{Al}_{\mathrm{KCl}}$ form was higher in the Jizerské Mountains. Figure 3 and Table 2 depicts the distribution of $\mathrm{Al}_{\mathrm{ORG}}$ concentrations and of $\mathrm{Al}$ species in the
Fig. $3 \mathrm{Al}$ forms and species distribution in organic $(\mathrm{O})$ and mineral (B) horizons in the studied areas (JM, Jizerské Mountains; NM, Novohradské Mountains)

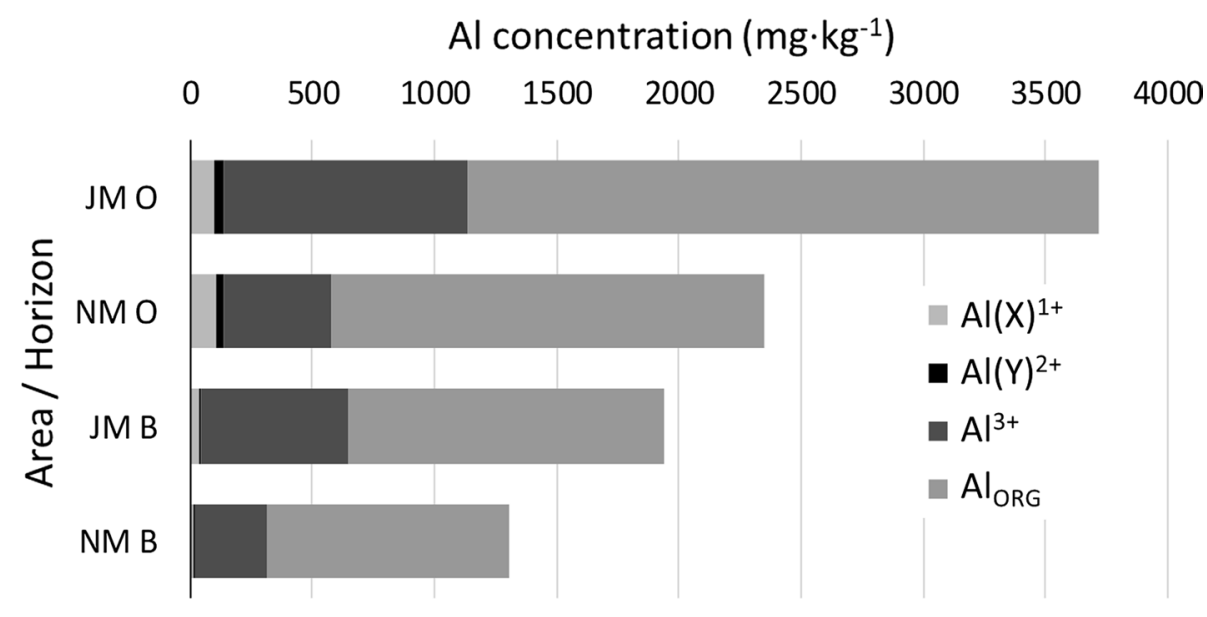


Table 2 Mean concentrations of Al species in the Jizerské Mountains (JM) and Novohradské Mountains (NM) and in each soil horizon. $N$, sample size; CV, coefficient of variation; bolded $t$ values indicate statistically significant differences between the two areas $(p<0.001)$

\begin{tabular}{|c|c|c|c|c|c|c|c|}
\hline \multirow[t]{2}{*}{ Site } & \multirow[t]{2}{*}{ Statistic } & \multicolumn{3}{|l|}{ O horizon } & \multicolumn{3}{|l|}{ B horizon } \\
\hline & & $\mathrm{Al}(\mathrm{X})^{1+}\left(\mathrm{mg} \mathrm{kg}^{-1}\right)$ & $\mathrm{Al}(\mathrm{Y})^{2+}\left(\mathrm{mg} \mathrm{kg}^{-1}\right)$ & $\mathrm{Al}^{3+}\left(\mathrm{mg} \mathrm{kg}^{-1}\right)$ & $\mathrm{Al}(\mathrm{X})^{1+}\left(\mathrm{mg} \mathrm{kg}^{-1}\right)$ & $\mathrm{Al}(\mathrm{Y})^{2+}\left(\mathrm{mg} \mathrm{kg}^{-1}\right)$ & $\mathrm{Al}^{3+}\left(\mathrm{mg} \mathrm{kg}^{-1}\right)$ \\
\hline \multirow[t]{3}{*}{$\mathrm{JM}$} & Mean & 101.16 & 36.71 & 999.57 & 34.14 & 10.09 & 604.15 \\
\hline & $N$ & 32 & 33 & 33 & 39 & 38 & 39 \\
\hline & $\mathrm{CV}$ & 38.30 & 27.41 & 38.72 & 50.71 & 35.91 & 23.33 \\
\hline \multirow[t]{5}{*}{ NM } & Mean & 106.17 & 27.51 & 446.16 & 12.04 & 4.96 & 296.07 \\
\hline & $N$ & 50 & 48 & 50 & 53 & 52 & 54 \\
\hline & $\mathrm{CV}$ & 21.79 & 36.28 & 61.47 & 44.18 & 38.33 & 30.02 \\
\hline & $t$ & -2.00 & 4.24 & 7.39 & 6.54 & 5.55 & 6.95 \\
\hline & $p$ & 0.049 & $<0.001$ & $<0.001$ & $<0.001$ & $<0.001$ & $<0.001$ \\
\hline
\end{tabular}

$\mathrm{KCl}$ extract, in which the potentially toxic species $\mathrm{A} 1^{3+}$ is dominant. In both soil horizons, $\mathrm{A} 1^{3+}$ and $\mathrm{Al}(\mathrm{Y})^{2+}$ concentrations were significantly higher in the Jizerské Mountains. The concentration of the less dangerous $\mathrm{Al}(\mathrm{X})^{1+}$ species in organic soil horizons was slightly higher in the Novohradské Mountains. In particular, the univalent species often represents $\mathrm{Al}$ that is complexed with low molecular mass organic acids (Drábek et al. 2005). This fact documents the strong relationship of univalent $\mathrm{Al}$ species with dissolved organic carbon (containing organic acids) reported by Tejnecký et al. (2010).

\section{Relationships}

The $\mathrm{Al}_{\mathrm{KCl}}$ concentrations were lower in the more acidic region, which contradicts the widely accepted indirect relationship between the concentration of mobile $\mathrm{Al}$ forms and soil reaction (Rengel 2003). Other soil variables such as base cations (Huang et al. 2014) or organic matter ( $\mathrm{Li}$ and Johnson 2016) could also be important in decreasing $\mathrm{Al}$ availability. For better understanding these relationships, we used a correlation analysis (separately for mountains and horizons; Tables 3, 4).

Concentrations of exchangeable $\mathrm{Al}$ form were correlated with almost all studied soil properties in the organic horizon of Jizerské Mountains. There is a difference in variables controlling $\mathrm{Al}_{\mathrm{KCl}}$ and $\mathrm{Al}_{\mathrm{ORG}}$ distribution in the $\mathrm{O}$ horizon. An interrelationship between both forms was found in the Novohradské Mountains but not in the Jizerské Mountains In the Jizerské Mountains, $\mathrm{Al}_{\mathrm{ORG}}$ distribution was controlled mainly by $\mathrm{C}$ concentrations (correlations with $\mathrm{N}$ and $\mathrm{S}$ are associated with $\mathrm{C}$ ), and no analogous correlation was found for the Novohradské Mountains.

The concentration of $\mathrm{Al}_{\mathrm{KCl}}$ correlates with $\mathrm{S}$ concentrations in the organic horizon of the anthropogenically acidified area. A similar relationship was determined between the trivalent $\mathrm{Al}$ species and S concentration in Drábek et al. (2005) and with sulphate concentration in Tejnecký et al.
(2010). A higher sulphate content affects the soil acidity and transforms hydroxylated $\mathrm{Al}$ species to $\mathrm{Al}^{3+}$ (Jones et al. 2011; Shaw and Hendry 2009). This relationship could differentiate the control mechanisms of $\mathrm{Al}$ speciation in anthropogenically acidified areas from natural systems in the Novohradské Mountains where no relationships was found between $\mathrm{Al}$ and $\mathrm{S}$ concentrations. More apparent is a sulphur effect shown by a strong direct correlation of $\mathrm{Al}_{\mathrm{KCl}}$ with the molar ratio $\mathrm{S}$ to $\mathrm{Ca}$ in the Jizerske Mountains. A logarithmic fit (Fig. 4) better described this relationship than did a linear fit (coefficients of determination: $R^{2} \log$ : 0.310; $R^{2}$ lin, 0.229).

Nitrogen deposition becomes a primary driving factor of anthropogenic soil acidification after a decrease in sulphur dioxide emission (e.g., Larssen et al. 2011). Nitrogen addition accelerates soil acidification, which then greatly decreases soil pH and base saturation (Mao et al. 2017). A weak relationship between $\mathrm{N}$ and the available $\mathrm{Al}$ form was also found in organic horizons of the acidified Jizerské Mountains, but not in the Novohradské Mountains. Lu et al. (2014) mentioned that long-term $\mathrm{N}$ addition did not change the soil concentration of exchangeable $\mathrm{Al}^{3+}$, but increased the exchangeable $\mathrm{H}^{+}$proportion in soil cation pools.

Different relationships were found in the mineral horizons (Table 4). The $\mathrm{Al}_{\mathrm{KCl}}$ concentration was mainly controlled by $\mathrm{pH}$ and partially by $\mathrm{C}$ and $\mathrm{N}$ concentrations at both mountains.

\section{Conclusions}

The basic soil characteristics differed between the anthropogenically acidified Jizerské Mountains and the naturally acidified Novohradské Mountains. The main differences were apparent in the organic horizon. Higher sulphur, nitrogen, exchangeable and organically bound $\mathrm{Al}$ concentrations were found in the anthropogenically acidified mountains, although these mountains also had a higher soil $\mathrm{pH}$. 
Table 3 Correlation coefficients of the relationships between $\mathrm{Al}$ forms and basic soil characteristics in the $\mathrm{O}$ horizon of Jizerské Mountains and Novohradské Mountains
Table 4 Correlation coefficients of the relationships between $\mathrm{Al}$ forms and basic soil characteristics in the $\mathrm{B}$ horizon of the Jizerské and the Novohradské Mountains

\begin{tabular}{lllllllllll}
\hline Variable & $\mathrm{Al}_{\mathrm{KCl}}$ & $\mathrm{Al}_{\mathrm{ORG}}$ & $\mathrm{pH}_{\mathrm{H} 2 \mathrm{O}}$ & $\mathrm{pH}_{\mathrm{KCl}}$ & $\mathrm{C}$ & $\mathrm{S}$ & $\mathrm{N}$ & $\mathrm{Mg}$ & $\mathrm{Ca}$ & $\mathrm{S} / \mathrm{Ca}$ \\
\hline
\end{tabular}

Jizerské Mountains

$$
\begin{array}{lllllllll}
\mathrm{Al}_{\mathrm{KCl}} & & & & & & & & \\
\mathrm{Al}_{\mathrm{ORG}} & 0.092 & & & & & & & \\
\mathrm{pH}_{\mathrm{H} 2 \mathrm{O}} & -0.342 & 0.166 & & & & & & \\
\mathrm{pH}_{\mathrm{KCl}} & -0.328 & 0.347 & \mathbf{0 . 7 0 0} & & & & & \\
\mathrm{C} & \mathbf{0 . 4 2 2} & \mathbf{0 . 4 9 8} & -0.170 & -0.087 & & & & \\
\mathrm{~S} & 0.333 & \mathbf{0 . 5 8 1} & -0.117 & 0.018 & \mathbf{0 . 7 8 7} & & & \\
\mathrm{N} & 0.296 & \mathbf{0 . 5 5 5} & 0.049 & 0.136 & \mathbf{0 . 9 1 3} & \mathbf{0 . 8 9 2} & & \\
\mathrm{Mg} & \mathbf{- 0 . 3 9 0} & -0.175 & 0.327 & 0.195 & -\mathbf{0 . 4 3 0} & \mathbf{- 0 . 4 5 9} & \mathbf{- 0 . 4 5 5} & \\
\mathrm{Ca} & \mathbf{- 0 . 3 4 4} & 0.170 & 0.198 & 0.167 & 0.106 & -0.099 & -0.038 & \mathbf{0 . 5 7 7} \\
\mathrm{S} / \mathrm{Ca} & \mathbf{0 . 4 7 9} & 0.228 & -0.156 & -0.008 & 0.413 & & \mathbf{0 . 5 3 0} & \mathbf{- 0 . 5 9 7}
\end{array}
$$

Novohradské Mountains

$$
\begin{array}{lllllllll}
\mathrm{Al}_{\mathrm{KCl}} & & & & & & & \\
\mathrm{Al}_{\mathrm{ORG}} & \mathbf{0 . 4 7 2} & & & & & & \\
\mathrm{pH}_{\mathrm{H} 2 \mathrm{O}} & -0.136 & 0.157 & & & & & \\
\mathrm{pH}_{\mathrm{KCl}} & -0.159 & \mathbf{0 . 4 0 0} & 0.189 & & & & \\
\mathrm{C} & 0.233 & 0.125 & -0.047 & \mathbf{- 0 . 6 2 0} & & & & \\
\mathrm{S} & 0.279 & 0.273 & -0.028 & \mathbf{- 0 . 5 4 2} & \mathbf{0 . 8 3 0} & & & \\
\mathrm{N} & 0.143 & 0.130 & -0.054 & \mathbf{- 0 . 5 0 6} & \mathbf{0 . 8 7 5} & \mathbf{0 . 9 0 9} & & \\
\mathrm{Mg} & -0.086 & 0.283 & 0.236 & \mathbf{0 . 7 6 0} & \mathbf{- 0 . 5 1 9} & \mathbf{- 0 . 4 6 1} & \mathbf{- 0 . 4 5 4} & \\
\mathrm{Ca} & -0.239 & -0.074 & 0.002 & \mathbf{- 0 . 3 2 0} & \mathbf{0 . 5 1 6} & 0.358 & \mathbf{0 . 4 1 9} & -0.233 \\
\mathrm{~S} / \mathrm{Ca} & 0.262 & 0.136 & -0.112 & -0.030 & -0.182 & & -0.083 & -0.061
\end{array}
$$

Probability level $0.001,0.010$, and 0.050 for the significant difference is denoted by bold, bolditalics, and italics, respectively

\begin{tabular}{lllllllllll}
\hline Variable & $\mathrm{Al}_{\mathrm{KCl}}$ & $\mathrm{Al}_{\mathrm{ORG}}$ & $\mathrm{pH}_{\mathrm{H} 2 \mathrm{O}}$ & $\mathrm{pH}_{\mathrm{KCl}}$ & $\mathrm{C}$ & $\mathrm{S}$ & $\mathrm{N}$ & $\mathrm{Mg}$ & $\mathrm{Ca}$ & $\mathrm{S} / \mathrm{Ca}$ \\
\hline
\end{tabular}

Jizerské Mountains

$\begin{array}{llllllllll}\mathrm{Al}_{\mathrm{KCl}} & & & & & & & & \\ \mathrm{Al}_{\mathrm{ORG}} & -0.026 & & & & & & & \\ \mathrm{pH}_{\mathrm{H} 2 \mathrm{O}} & -0.403 & 0.127 & & & & & & \\ \mathrm{pH}_{\mathrm{KCl}} & -\mathbf{0 . 4 3 8} & 0.223 & \mathbf{0 . 7 3 2} & & & & & \\ \mathrm{C} & 0.350 & 0.241 & 0.106 & -0.121 & & & & \\ \mathrm{~S} & 0.227 & 0.317 & -0.072 & -0.147 & \mathbf{0 . 8 9 8} & & & \\ \mathrm{N} & 0.373 & 0.375 & -0.036 & -0.202 & \mathbf{0 . 9 1 2} & \mathbf{0 . 9 1 6} & & \\ \mathrm{Mg} & -0.107 & -0.099 & 0.366 & 0.376 & -0.032 & -0.226 & -0.151 & \\ \mathrm{Ca} & 0.021 & -0.199 & 0.265 & 0.119 & -0.029 & -0.207 & -0.070 & 0.495 \\ \mathrm{~S} / \mathrm{Ca} & 0.121 & \mathbf{0 . 4 7 5} & -0.124 & -0.049 & \mathbf{0 . 6 5 9} & & \mathbf{0 . 6 9 7} & -0.364\end{array}$

Novohradské Mountains

$$
\begin{array}{lllllllll}
\mathrm{Al}_{\mathrm{KCl}} & & & & & & & & \\
\mathrm{Al}_{\mathrm{ORG}} & 0.113 & & & & & & & \\
\mathrm{pH}_{\mathrm{H} 2 \mathrm{O}} & -0.244 & 0.271 & & & & & & \\
\mathrm{pH}_{\mathrm{KCl}} & \mathbf{- 0 . 6 3 7} & 0.142 & 0.296 & & & & & \\
\mathrm{C} & 0.328 & \mathbf{0 . 8 3 1} & 0.202 & -0.078 & & & & \\
\mathrm{~S} & -0.037 & 0.017 & -0.052 & 0.286 & 0.218 & & & \\
\mathrm{~N} & 0.324 & \mathbf{0 . 6 0 2} & 0.115 & -0.119 & \mathbf{0 . 9 0 3} & 0.279 & & \\
\mathrm{Mg} & -0.176 & \mathbf{- 0 . 3 2 9} & -0.140 & 0.292 & \mathbf{- 0 . 3 6 6} & 0.287 & -0.203 & \\
\mathrm{Ca} & 0.078 & -0.009 & -0.002 & 0.065 & -0.050 & 0.172 & 0.100 & 0.309 \\
\mathrm{~S} / \mathrm{Ca} & 0.029 & 0.097 & 0.019 & -0.102 & 0.343 & & 0.216 & -0.236
\end{array}
$$

Probability level $0.001,0.010$, and 0.050 for the significant difference is denoted by bold, bolditalics, and italics, respectively 


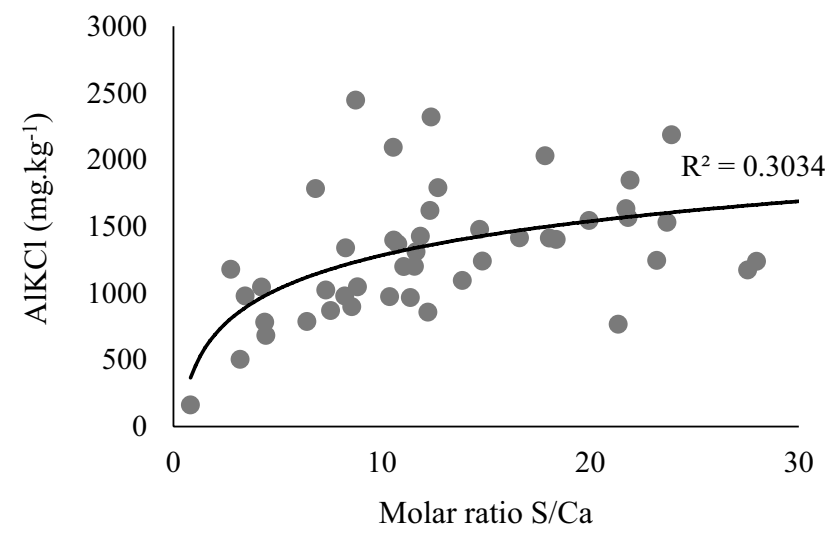

Fig. 4 Relationships between exchangeable $\mathrm{Al}\left(\mathrm{Al}_{\mathrm{KCl}}\right)$ and molar ratio $\mathrm{S} / \mathrm{Ca}$ in the $\mathrm{O}$ horizon of the Jizerské Mountains. Logarithmic fit is shown

The potential $\mathrm{Al}$ toxicity represented by $\mathrm{Al}_{\mathrm{KCl}}$ and especially the trivalent $\mathrm{Al}$ species was significantly higher in the organic and mineral horizons of the Jizerské Mountains. The $\mathrm{Al}$ speciation was affected by different acidification levels of studied regions. Speciation differences were more apparent in the organic horizons than in the mineral horizons.

Some of the mechanisms, such as the known relationship of $\mathrm{Al}$ with the soil $\mathrm{pH}$ in the mineral horizon controlling $\mathrm{Al}$ distribution are similar in both mountains, while others differed. A direct relationship of $\mathrm{Al}_{\mathrm{KCl}}$ concentrations with sulphur concentrations and even more so with the molar ratio S/Ca were found only in the acidified Jizerské Mountains, but not in the Novohradské Mountains.

Generally, the obtained results support the hypothesis that the mechanisms responsible for natural acidification and anthropogenic acidification differ. Low soil $\mathrm{pH}$ that results from the presence of organic acids does not necessarily represent a high risk that toxic forms of $\mathrm{Al}$ will be released due to the complexing ability of the organic acids. In contrast, anthropogenic acidification by mineral acids led to a release of potentially toxic $\mathrm{Al}$ forms, which could affect forest health.

Open Access This article is distributed under the terms of the Creative Commons Attribution 4.0 International License (http://creativeco mmons.org/licenses/by/4.0/), which permits unrestricted use, distribution, and reproduction in any medium, provided you give appropriate credit to the original author(s) and the source, provide a link to the Creative Commons license, and indicate if changes were made.

\section{References}

Borůvka L, Mládková L, Drábek O (2005) Factors controlling spatial distribution of soil acidification and $\mathrm{Al}$ forms in forest soils. J Inorg Biochem 99:1796-1806

Borůvka L, Nikodem A, Drábek O, Vokurková P, Tejnecký V, Pavlů L (2009) Assessment of soil aluminium pools along three mountainous elevation gradients. J Inorg Biochem 103:1449-1458

Boudot JP, Becquer T, Merlet D, Rouiller J (1994) Aluminium toxicity in declining forests: a general overview with a seasonal assessment in a silver fir forest in the Vosges mountains (France). Ann For Sci 51:27-51

Bowman WD, Cleveland CC, Halada L, Hresko J, Baron JS (2008) Negative impact of nitrogen deposition on soil buffering capacity. Nat Geosci 1:767-770

CHMI (2019) Portal of Czech Hydrometeorologila Institute- -historical data. http://portal.chmi.cz/files/portal/docs/uoco/isko/grafroc/ groc/gr96cz/groc96.html. Accessed 20 May 2019

Collignon C, Boudot JP, Turpault MP (2012) Time change of aluminiumtoxicity in the acid bulk soil and rhizosphere in Norway spruce (Picea abies (L) Krast) and (Fagus sylvatica L) stands. Plant Soil 357:259-274

Drábek O, Borůvka L, Mládková L, Kočárek M (2003) Possible method of aluminium speciation in forest soils. J Inorg Biochem 97:8-15

Drábek O, Mládková L, Borůvka L, Száková J, Nikodem A, Němeček $\mathrm{K}$ (2005) Comparison of water-soluble and exchangeable forms of $\mathrm{Al}$ in acid forest soils. J Inorg Biochem 99:1788-1795

Drábek O, Borůvka L, Pavlů L, Nikodem A, Pírková I, Vacek O (2007) Grass cover on forest clear-cut areas ameliorates soil chemical properties. J Inorg Biochem 101:1224-1233

Gupta N, Gaurav SS, Kumar A (2013) Molecular basis of aluminium toxicity in plants: a review. Am J Plant Sci 4:21-37

Huang J, Mo JM, Zhang W, Lu XK (2014) Research on acidification in forest soil driven by atmospheric nitrogen deposition. Acta Ecol Sin 34:302-310

IUSS (2019) World reference base for soil resources 2014. World soil resources reports no. 106, Rome, FAO. http://www.fao.org/publi cations/card/en/c/942e424c-85a9-411d-a739-22d5f8b6cc41/. Accessed 31 Oct 2019

Jones AM, Collins RN, Waite TD (2011) Mineral species control of aluminum solubility in sulfate-rich acidic waters. Geochim Cosmochim Acta 75:965-977

Kinraide TB (1991) Identity of the rhizotoxic aluminium species. Plant Soil 134:167-178

Kopáček J, Veselý J (2005) Sulfur and nitrogen emissions in the Czech Republic and Slovakia from 1850 till 2000. Atmos Environ 39:2179-2188

Larssen T, Carmichael GR (2000) Acid rain and acidification in China: the importance of base cations deposition. Environ Pollut 110:89-102

Larssen T, Duan L, Mulder J (2011) Deposition and leaching of sulphur, nitrogen and calcium in four forested catchments in China: implications for acidification. Environ Sci Technol 45:1192-1198

Li W, Johnson CE (2016) Relationships among pH, aluminum solubility and aluminum complexation with organic matter in acid forest soils of the Northeastern United States. Geoderma 271:234-242

Lu X, Mao Q, Gilliam FS, Luo Y, Mo J (2014) Nitrogen deposition contributes to soil acidification in tropical ecosystems. Glob Change Biol 20:3790-3801

Mao Q, Lu X, Zhou K, Chen H, Zhu X, Mori T, Mo J (2017) Effects of long-term nitrogen and phosphorus additions on soil acidification in an N-rich tropical forest. Geoderma 285:57-63

Pavlů L, Drábek O, Stejskalová Š, Tejnecký V, Hradilová M, Nikodem A, Borůvka L (2018) Distribution of aluminium fractions in acid 
forest soils: influence of vegetation changes. iForest Biogeosci For 11:721-727

Pohlman AA, McColl JG (1988) Soluble organics from forest litter and their role in metal dissolution. Soil Sci Soc Am J 52:265-271

Rengel Z (2003) Handbook of soil acidity. Marcel Dekker Inc, New York, p 496

Schmitt M, Watanabe T, Jansen S (2016) The effects of aluminium on plant growth in a temperate and deciduous aluminium accumulating species. AoB Plants 8:plw065

Shaw SA, Hendry MJ (2009) Geochemical and mineralogical impacts of $\mathrm{H}_{2} \mathrm{SO}_{4}$ on clays between $\mathrm{pH} 5.0$ and 3.0. Appl Geochem $24: 333-345$

Singha S, Tripathib DK, Singha S, Sharmac S, Dubeyb NK, Chauhana DK, Vaculík M (2017) Toxicity of aluminium on various levels of plant cells and organism: a review. Environ Exp Bot 137:177-193

Smith SJ, van Aardenne J, Klimont Z et al (2011) Anthropogenic sulphur dioxide emissions: 1850-2005. Atmos Chem Phys 11:1101-1116

Stevens CJ, Thompson K, Grime JP, Long CJ, Gowing DJF (2010) Contribution of acidification and eutrophication to declines in species richness of calcifuge grasslands along a gradient of atmospheric nitrogen deposition. Funct Ecol 24:478-484

Suchara I, Sucharová J (2002) Distribution of sulphur and heavy metals in forest floor humus of the Czech Republic. Water Air Soil Pollut 136:289-316

Sucharová J, Suchara I, Holá M, Reimann C, Boyd R, Filzmoser P, Englmaier P (2011) Linking chemical elements in forest floor humus (Oh-horizon) in the Czech Republic to contamination sources. Environ Pollut 159:1205-1214

Tejnecký V, Drábek O, Borůvka L, Nikodem A, Kopáč J, Vokurková P, Šbek O (2010) Seasonal variation of water extractable aluminium forms in acidified forest organic soils under different vegetation cover. Biogeochemistry 101:151-163

Publisher's Note Springer Nature remains neutral with regard to jurisdictional claims in published maps and institutional affiliations. 